НАУКОВИЙ ВІСНИК

Scientific messenger of Lviv National University of
Veterinar Medicine and Biotechnologies
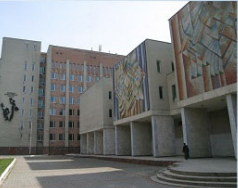

СЕРЯ: ВЕТЕРИНАРНH НАYКИ
Науковий вісник Аьвівського національного університету ветеринарної медицини та біотехнологій імені С.3. Гжицького. Серія: Ветеринарні науки

Scientific Messenger of Lviv National University of Veterinary Medicine and Biotechnologies. Series: Veterinary sciences

UDC 616-001.41: 615.468.72

\title{
Treatment of postoperative wounds using pectin-based reinforced dressings and their antimicrobial activity
}

\author{
V. Vlizlo ${ }^{1}$, A. Mysak ${ }^{1}$, V. Stybel ${ }^{1}$, R. Voloshyn ${ }^{1}$, Yu. Leno ${ }^{1}$, N. Kuz'mina ${ }^{2}$, M. Kozak ${ }^{2}$, Yu. Bodnar ${ }^{2}$, \\ I. Petpuh ${ }^{2}$, D. Ostapiv ${ }^{2}$, I. Dron' ${ }^{3}$, V. Samaryk ${ }^{3}$, N. Bukartyk ${ }^{3}$, N. Nosova ${ }^{3}$, S. Varvarenko $^{3}$ \\ ${ }^{1}$ Stepan Gzhytskyi National University of Veterinary Medicine and Biotechnologies Lviv, Lviv, Ukraine \\ ${ }^{2}$ Institute of Animal Biology, NAAS of Ukraine, Lviv, Ukraine \\ ${ }^{3}$ Lviv Polytechnic National University, Lviv, Ukraine
}

Article info

Received 17.09.2021 Received in revised form 18.10.2021

Accepted 19.10.2021

Stepan Gzhytskyi National University of Veterinary Medicine and Biotechnologies Lviv, Pekarska Str., 50, Lviv, 79010, Ukraine.

Institute of Animal Biology, Naas of Ukraine Lviv, V. Stusa Str., 38, Lviv, 79034, Ukraine. Tel.: +380-32-260-07-95 E-mail:inenbiol@mail.lviv.ua

Lviv Polytechnic National University, Bandera street, 12, Lviv, 79013, Ukraine.

Tel.: +380-32-258-21-11 E-mail: coffice@lpnu.ua
Vlizlo, V., Mysak, A., Stybel, V., Voloshyn, R., Leno, Yu., Kuz'mina, N., Kozak, M., Bodnar, Yu., Petpuh, I., Ostapiv, D., Dron, I., Samaryk, V., Bukartyk, N., Nosova, N., \& Varvarenko, S. (2021). Treatment of postoperative wounds using pectin-based reinforced dressings and their antimicrobial activity. Scientific Messenger of Lviv National University of Veterinary Medicine and Biotechnologies. Series: Veterinary sciences, 23(104), 41-46. doi: 10.32718/nvlvet10407

A reinforced pectin-based dressing with a reinforcing element containing the antimicrobial agent chlorhexidine bigluconate has been developed. In vitro studies have shown that the hydrogel pectin dressing containing $0.03 \div 1.5 \%$ chlorhexidine bigluconate inhibits the growth of both gram-positive (S. aureus) and gram-negative ( $P$. aeruginosa) bacteria. The dressing can be used in the complex treatment of postoperative wounds with infectious-inflammatory process. The efficacy of different doses of chlorhexidine bigluconate was characterized by growth inhibition and increase of microorganism-free areas on the culture medium around the site of dressing localization, and regardless of the type of bacteria. Bacterial growth inhibition radius size depends on the dose of chlorhexidine in the hydrogel pectin dressing. The inhibition of growth of $S$. aureus and $P$. aeruginosa is directly proportional to chlorhexidine bigluconate content. The increase of dressing saturation with chlorhexidine to 1.0 and $1.5 \%$ recorded the maximum inhibition of the growth of microorganisms. A veterinary clinical trial has shown a good therapeutic effect in the wound healing, in particular in the complex treatment of postoperative and accidental wounds both in the presence of infectious-inflammatory process and in its absence. The reinforced pectin-based dressing with cotton (or polypropylene) reinforcement element containing chlorhexidine bigluconate reduces the cost of dressings and bandaging frequency during wound healing. It protects the wound surface from contamination, mechanical irritation, bacterial contamination and the development of secondary infection. The dressing promotes good water, air and heat exchange between the wound and the environment, adsorbs excess exudate, maintains a moist environment and does not cause hyperosmotic damage and drying of the wound. Surgical wound healing occurred under the initial tension for 7 days. Considering the method of its application, this dressing is suitable for use on different parts of the animal's body (neck, withers, chest and abdomen, lower back, buttocks, thighs, shoulders, etc.).

Key words: postoperative wounds, dressings, hydrogel, antimicrobial activity, chlorhexidine.

\section{Терапія післяопераційних ран армованими пов'язками на основі пектину та їх протимікробна дія}

В. Влізло ${ }^{1}$, А. Мисак ${ }^{1}$, В. Стибель ${ }^{1}$, Р. Волошин ${ }^{1}$, Ю. Леньо $^{1}$, Н. Кузьміна ${ }^{2}$, М. Козак ${ }^{2}$, Ю. Боднар $^{2}$, I. Петрух ${ }^{2}$, Д. Остапів ${ }^{2}$, І. Дронь ${ }^{3}$, В. Самарик ${ }^{3}$, Н. Букартик ${ }^{3}$, Н. Носова ${ }^{3}$, С. Варваренко ${ }^{3}$

${ }^{1}$ Львівський національний університет ветеринарної медицини та біотехнологій імені С. 3. Гәсицького, м. Львів, Україна 
${ }^{2}$ Інститут біології тварин НААН, м. Львів, Україна

${ }^{3}$ Національний університет “Львівська політехніка”, м. Львів, Украӥна

Розроблено армовану пов'язку на основі пектину з елементом армування, шуо містить антимікробний засіб хлоргексидин біглюконат. Проведені дослідження іп vitro показали, шуо гідрогелева пектинова пов 'язка з вмістом 0,03 - $1,5 \%$ олоргексидину біглюконату пригнічує ріст як грампозитивних (S. аигеus), так і грамнегативних (P. аегиgіпова) бактерій. Завдяки иььму пов 'язка може бути використана і за комплексного лікування післяопераційних ран з інфекційно-запальним прочесом. Ефективність дії різних доз хлоргексидину біглюконату характеризувалася пригніченням росту та збільшенням вільного від мікроорганізмів зон середовища культивування навколо місия локалізації пов'язки з діючою речовиною, незалежно від виду бактерій. Однак величина діаметру зони пригнічення росту бактерій залежить від дози хлоргексидину в гідрогелевій пектиновій пов'язці. За пропориійного підвищення вмісту хлоргексидину біглюконату інгібування росту S. аигеиs $i$ P. aеruginosa посилюється. Так, коли збільшували насичення пов'язки хлоргексидином до 1,0 і 1,5\%, реєстрували максимальне інгібування росту мікроорганізмів. Клінічне дослідження показало добрий лікувальний ефект у ветеринарній практиці за терапії ран, зокрема за комплексного лікування післяопераційних і випадкових ран як за наявності інфекиійно-запального процесу, так $i$ за його відсутності. Застосування армованої пов'язки на основі пектину з бавовняним (чи поліпропіленовим) елементом армування з вмістом хлоргексидину біглюконату скорочує витрати перев'язувального матеріалу $і$ частоту перев'язок впродовж часу загоєння ран. Вона забезпечує захист ранової поверхні від забруднення, механічного подразнення, бактеріальної контамінації та розвитку вторинної інфекції. Пов 'язка сприяє доброму водо-, повітро- та теплообміну між раною та зовнішнім середовищем, адсорбує надлишок ексудату, підтримує вологе середовище і не викликає гіперосмотичного ушкодження й висихання рани. Загоювання післяопераційної рани відбулося за первинним натягом впродовж 7 діб. Зважаючи на спосіб накладання, дана пов'язка може бути придатна для застосування у різних ділянках тіла тварини (ииї, холки, грудної й черевної стінок, попереку, крижів, стегна, плеча тощо).

Ключові слова: післяоперачійні рани, пов'язки, гідрогель, протимікробна дія, хлоргексидин.

\section{Вступ}

Для швидкого проходження етапів загоєння ран важливим $є$ використання ефективних пов'язок. Основна функція накладеної пов'язки - це адсорбія ранового ексудату, ізоляція рани від навколишнього середовища, забезпечення на місці ранового середовища сприятливого мікроклімату з доступом Оксигену, підтриманням необхідної вологості, $\mathrm{pH}$ та інше (Abayev, 2006).

Серед пов'язок найбільш поширений перев'язувальний матеріал, який використовується в хірургії, є марля. Марля виготовлена 3 натуральної бавовняної тканини, яка здатна поглинати в 10 разів більший об'єм рідини, ніж власна вага та характеризується помірною дренажною функцією і дешевизною виробництва (Blednov, 2006). Крім марлевих пов’язок, як перев’язувальний матеріал використовують плівки, гідрогелі, гідроколлоїди, піни, альгінати. Плівки, гідрогелі та гідроколлоїди належать до типу перев'язувального матеріалу, який створює і підтримує оптимальний рівень вологості в рановій порожнині (Li et al., 2020). Своєю чергою дія пінів і альгінатів грунтується на абсорбції надлишку вологи (Andreyev et al., 2009; Anghel, 2012). Проте вказані пов'язки мають низку недоліків. Зокрема, у марлевих пов'язок відсутня селективність, вони мають високу адгезивність, низькі поглинальні властивості вже через 8-12 годин після накладання. Такі пов'язки нерідко прилипають до рани і залишають в ній волокна, що призводить до вторинного забруднення і травмування рани, болісної процедури зняття з рани, що спричиняє тривалий період лікування (Shablovskaya \& Panchenkov, 2013).

Застосування пов'язок з плівок веде до активування інфекційного запального процесу в рані, а якщо на поверхні рани накопичується серозний ексудат, то виникають мацерації шкіри ураженої ділянки (Jones et al., 2006).
Використання гідрогелів і гідроколоїдів на ранову поверхню не забезпечує тривалої всмоктувальної здатності ексудату. При насичені їх ексудатом вони піддаються сильній деформації та потребують швидкої заміни (Caló \& Khutoryanskiy, 2015). Водночас застосування піни веде лише до надмірного підсушування верхнього шару шкіри та країв рани (Yamane et al., 2013).

Для гуманної та ветеринарної медицини в Україні та світі розробляються гідрогелеві пов'язки (Cheng et al., 2017). В останні роки було розроблено способи накладання антисептичних гідрогелевих пов'язок 3 гелеутворюючих полімерів високоестерифікованого пектину (ступінь естерифікації - 81,5 \%) та альгінату натрію, що дозволяє використовувати їх для лікування ран з середнім та високим виділенням ексудату. За тісного контакту даної пов'язки з поверхнею рани гель ефективно поглинає бактерії, що значно зменшує кількість мікроорганізмів в рані та перешкоджає вторинному iii інфікуванню (Dron' et al., 2020). Вказаний тип пов'язки ефективний за лікування виразок та інфікованих ран (Abayev, 2006). При цьому вони мають гелеподібну консистенцію, завдяки чому створюється ефект вологого середовища, що перешкоджає висиханню рани i, як наслідок, формується мікроклімат, сприятливий для росту грануляційної тканини. Крім цього, завдяки гелю такі пов'язки не приклеюються до рани і тому не спричиняють болю та дискомфорту за перев'язки. Однак за використання пов'язок на основі високоестерифікованого пектину та альгінату натрію часто трапляється їх набрякання на рані, тому необхідна додаткова фіксація поверхні іншим перев'язувальним матеріалом, зокрема марлею (Caló \& Khutoryanskiy, 2015). Це ускладнює роботу лікаря та веде до збільшення часу перебування перев'язки на рані. Тому у фазі запалення, коли необхідно очистити рану, залежно від ступеня інтенсивності ексудації, інколи необхідно за добу один-два рази змінювати пов'язки (Blednov, 2006). Тому ці пов'язки потребують удосконалення для поліпшення лікувального 
ефекту. Як було виявлено у попередніх дослідженнях, гідрогелева пов'язка на основі пектину з бавовняним чи поліпропіленовим елементом армування та вмістом хлоргексидину біглюконату $€$ єфективною за лікування ран (Nosova et al., 2021; Mysak et al., 2021; Ostapiv et al., 2021).

Метою роботи було розробити та апробувати у клінічній ветеринарній медицині для терапії післяопераційних ран у великої рогатої худоби армовану гідрогелеву пектинову пов'язку з поліпропіленовими елементами армування та вивчити антимікробну дію хлоргексидину біглюконату, яким насичують пов'язку в умовах пролонгованого дифузійного вивільнення його з об'єму пов'язки.

\section{Матеріал і методи досліджень}

Гідрогелеву основу пов'язки виготовляли за методикою, описаною в роботі (Dron' et al., 2020). Для одержання гідрогелів на основі пектину та альгінату

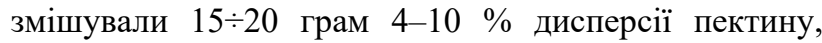
$5 \div 10$ грам 3,5 \% дисперсії альгінату натрію, додавали необхідну кількість пластифікаторів (співвідношення ППГ 2000 : ПЕГ 4500 як 3:1). Одержану суміш ретельно перемішували, завантажували у форми, поміщали у 100-200 мл 0,2-1 \% розчину хлориду кальцію та витримували 10-20 годин. Гідрогелі виймали 3 форми, промивали водою, зберігали за температури 5 ㄷ. Для можливості використання описаних гідрогелів як антисептичних пов'язок для ветеринарії їх насичували визначеною кількістю хлоргексидину біглюконату, попереднім набряканням в контрольованій кількості його $10 \%$ водного розчину. Крім того, при формуванні гідрогелю в його об'єм вводили елемент армування у вигляді поліпропіленової сітки, поверхня якої була модифікована за методикою, описаною в роботі (Nosova et al., 2020). Модифікація поверхні поліпропіленової сітки забезпечує іiі ковалентне зв'язування $з$ гелеутворюючим полімером, що надає виробу необхідних фізико-механічних властивостей.

Для вивчення впливу гідрогелевої пектинової пов'язки 3 хлоргексидином біглюконатом на інтенсивність росту бактерій було використано музейні штами $S$. aureus та $P$. aeruginosa. Для приготування іно- куляту у пробірку з 10 мл поживного середовища (4 \% глюкози і 1 \% м'ясо-пептонного бульйону; поживний бульйон; ТОВ “Фармреактив”) петлею переносили $S$. aureus та $P$. aeruginosa та інкубували впродовж 24 год за температури $30 \pm 2{ }^{\circ} \mathrm{C}$.

Для культивування готували середовище $31 \%$ м'ясо-пептонного агару (МПА) $34 \%$ глюкозою, яке розливали в чашки Петрі (приблизно 20 мл на чашку) i формували нижній шар середовища, неінокульованого тест-мікрорганізмом. Для формування верхнього шару середовища, інокульованого тестмікрорганізмом (інокулят), у 100 мл поживного середовища додавали 10 мл суспензії тест-мікроорганізму, перемішували і розливали по 5 мл поверх нижнього шару після його застигання (температура середовища не перевищувала $\left.40-45^{\circ} \mathrm{C}\right)$.

Для виявлення впливу армованої гідрогелевої пектинової пов'язки 3 хлоргексидином біглюконатом готували зразки пов'язок з вмістом: 0,030, 0,050, $0,075,0,10,0,40,1,00$ i 1,50 \% хлоргексидину біглюконату. 3 виготовлених зразків вирізали диски ( $\mathrm{d}=1 \mathrm{~cm})$, які ділили на дві рівні частини: одну вносили в чашки Петрі для культивування 3 культурою $S$. aureus, іншу - 3 P. aeruginosa. Культивували зразки впродовж 168 год за температури $30 \pm 2{ }^{\circ} \mathrm{C}$.

Підтвердження ефективності антисептичної пов'язки за лікування післяопераційних ран визначали шляхом накладання на поверхню рани армованої пов'язки на основі пектину з поліпропіленовим елементом армування з вмістом хлоргексидину біглюконату $(0,4 \div 1,5 \%)$.

Пов'язку застосовували на післяопераційну рану в ділянці черевної стінки великої рогатої худоби після проведення лапаротомії. Результати загоєння лапаротомної рани фіксували впродовж 7 діб, щодобово.

\section{Результати та їх обговорення}

Проведені нами дослідження in vitro показали, що гідрогелева пектинова пов'язка 3 вмістом $0,03 \div 1,5$ \% хлоргексидину біглюконату гальмує ріст як грампозитивних (S. aureus), так i грамнегативних (P. aeruginosa) бактерій (табл.).

\section{Таблиця}

Гальмування росту мікроорганізмів за дії гідрогелевої пектинової пов'язки з хлоргексидином біглюконатом, см $(\mathrm{n}=4 ; \mathrm{M} \pm \mathrm{m})$

\begin{tabular}{ccc}
\hline Концентрація хлоргексидину в гелі, \% & \multicolumn{2}{c}{ Величина радіусу гальмування росту, см } \\
S.aureus & P.aeruginosa \\
\hline 1,50 & $1,12 \pm 0,05$ & $1,13 \pm 0,03$ \\
1,00 & $1,06 \pm 0,05$ & $1,05 \pm 0,02$ \\
0,40 & $0,92 \pm 0,01$ & $0,90 \pm 0,01$ \\
0,10 & $0,85 \pm 0,01$ & $0,86 \pm 0,01$ \\
0,075 & $0,83 \pm 0,01$ & $0,83 \pm 0,01$ \\
0,050 & $0,78 \pm 0,01$ & $0,79 \pm 0,01$ \\
0,030 & $0,76 \pm 0,00$ & $0,77 \pm 0,01$ \\
\hline кореляційне відношення $\left(\eta^{2}\right)$ & 0,859 & 0,936 \\
сила впливу $(\mathrm{F})$ & 21,395 & 51,571 \\
\hline
\end{tabular}


При цьому, незалежно від виду бактерій, зона пригнічення росту не відрізнялися. Так, за мінімальної дози хлоргексидину в гелі $(0,030 \%)$ зона пригнічення росту становила $0,76-0,77 \mathrm{~cm}$, за $0,4 \%-0,90-0,92 \mathrm{~cm}$, а за максимальної дози $(1,5 \%)-1,12-1,13$ см. Аналіз залежності величин зони пригнічення росту бактерій від дози діючої речовини свідчить, що за пропорційного підвищення вмісту хлоргексидину в пов'язці інгібування росту є сильним: для P.aeruginosa $\eta^{2}=0,936$ i $S$. aureus $-\eta^{2}=0,859$.

Аналіз динаміки величин значень зон інгібування росту бактерій свідчить, що 0,4 \% концентрація хлоргексидину в гідрогелевій пектиновій пов'язці веде впродовж 48 год до максимального діаметру зони пригнічення росту $(0,77-0,94$ см), а через наступних 24 год (на 72 год) спостерігається зменшення ще на 0,002-0,029 см (рис. 1-4).

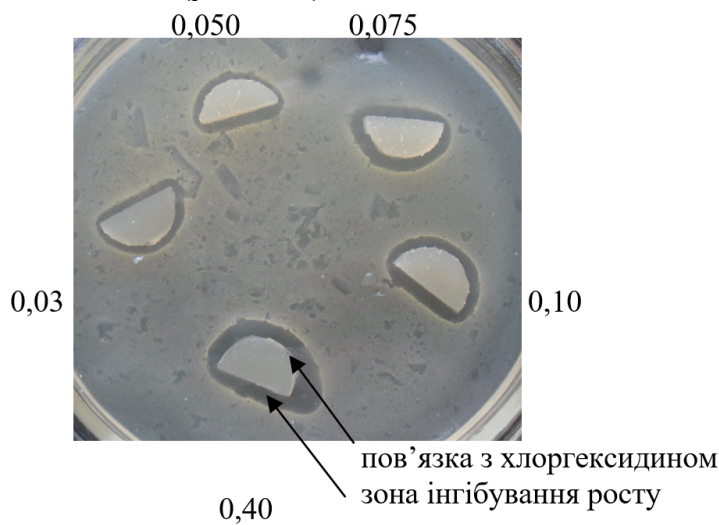

Рис. 1. Пригнічення росту S.aureus за впливу 0,030 $0,40 \%$ хлоргексидину в пов'язці через 72 год

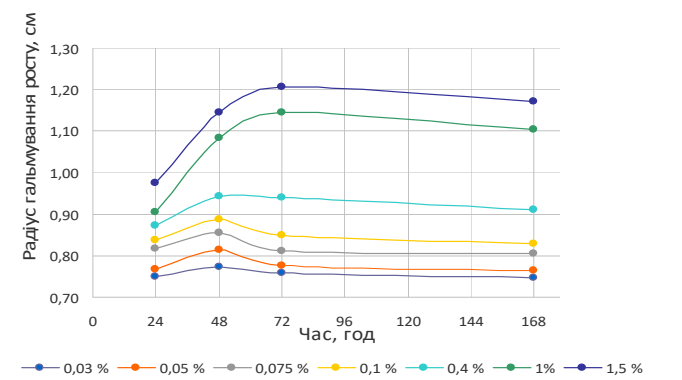

Рис. 2. Динаміка пригнічення росту S.aureus за впливу хлоргексидину в пов'язці протягом 168 год

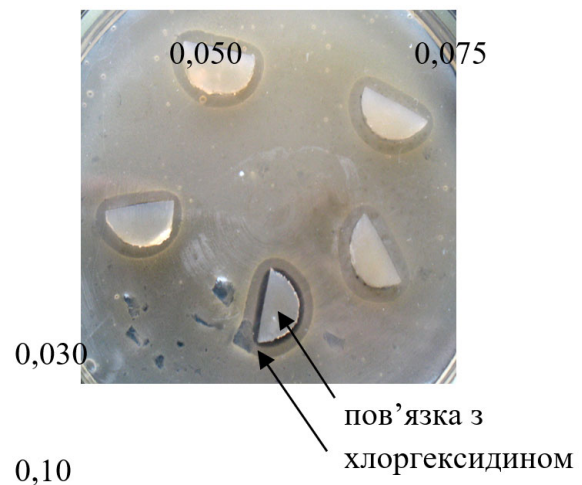

Рис. 3. Пригнічення росту $P$. aeruginosa за впливу $0,030-0,40 \%$ хлоргексидину в пов'язці через 72 год

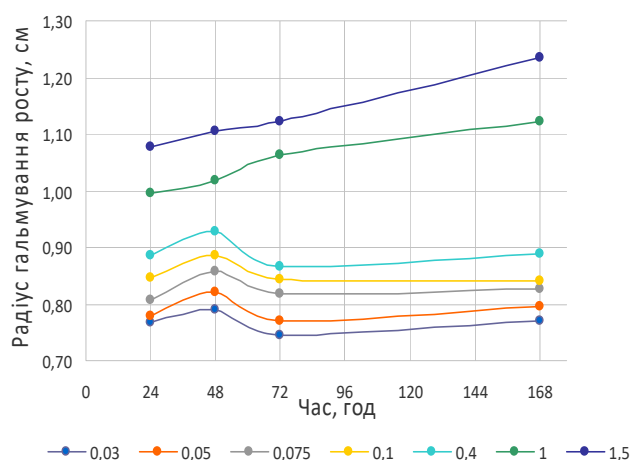

Рис. 4. Динаміка пригнічення росту $P$. aeruginosa за впливу хлоргексидину в пов'язці протягом 168 год

Подовження часу культивування понад 72 год не змінювало величини діаметру зони пригнічення росту бактерій за вказаних концентрацій хлоргексидину в пов'язці. Збільшення дози до 1,0 і 1,5 \% діючої речовини в складі гелю також призводить до гальмування росту бактерій. Однак максимальна величина значення діаметру інгібування росту (1,06-1,21 см) встановлена також через 72 год культивування. Подовження терміну культивування (понад 72 год) у зразках S. aureus проявлялося тенденцією до зменшення (на $0,03-0,04$ см) діаметру зони інгібування росту. Проте за вказаних умов пригнічення росту $P$. aeruginosa було максимальним (1,12-1,25 см) за 168 год культивування.

Отже, у складі гідрогелевої пектинової пов'язки хлоргексидин біглюконат ефективно гальмує ріст бактерій. При цьому збільшується діаметр зони пригнічення росту бактерій, що залежить від дози доданого хлоргексидину біглюконату в гідрогелеву пектинову пов'язку. Крім цього, незалежно від виду бактерій, ефективність дії кожної дози хлоргексидину біглюконату $є$ подібною і характеризується гальмуванням росту та збільшенням вільного від мікроорганізмів зон середовища культивування навколо місця локалізації пов'язки з діючою речовиною. За високого вмісту діючої речовини (1,0 і 1,5 \%) проявляється максимально ефективне інгібування росту - незалежно від виду мікроорганізмів.

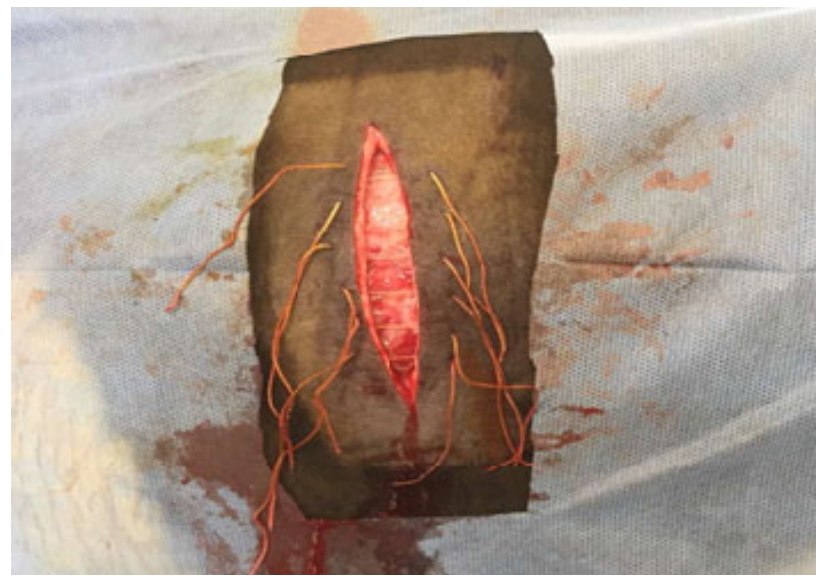

Рис. 5. Рана в ділянці черевної стінки великої рогатої худоби після проведення лапаротомії 
Після проведення операційного втручання (рис. 5) у ділянці голодної ямки (лапаратомії) було накладено пов'язку, яку закріплювали на поверхні рани частиною ниток, після зашивання шкірної рани наглухо вузловим швом та зав'язування вузлів.

Після цього частину ниток обрізали, а тими, що залишилися (кількість їх залежала від довжини рани), закріплювали пов’язку на поверхні рани (рис. 6).

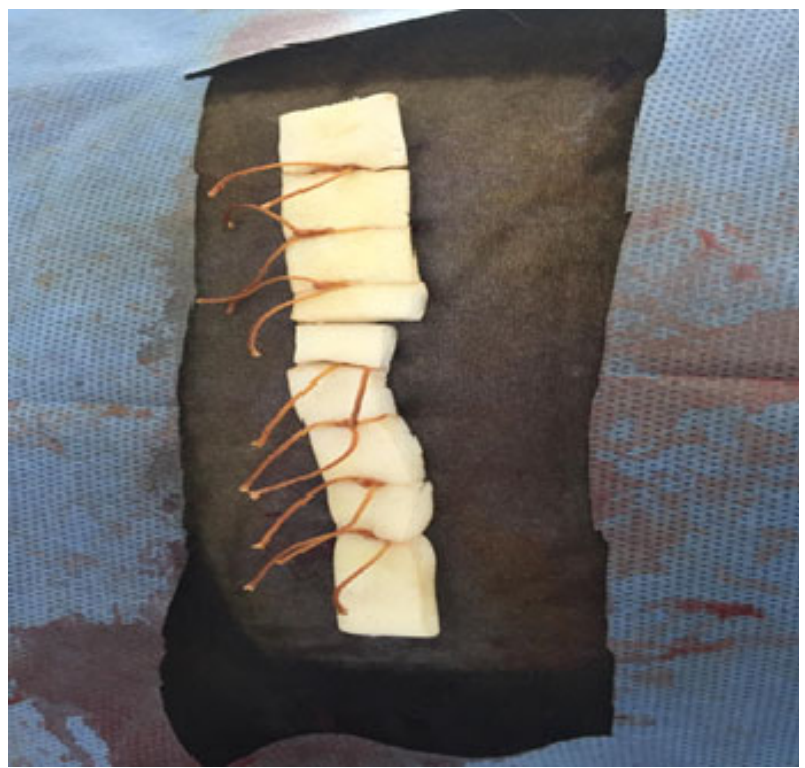

Рис. 6. Армована пов’язка на основі пектину 3

поліпропіленовим елементом армування з вмістом хлоргексидину біглюконату на післяопераційній рані в ділянці черевної стінки великої рогатої худоби після проведення лапаротомії

Контроль за рановою поверхнею показав позитивний результат використання армованої пов'язки на основі пектину уже протягом перших днів після лапаротомії. При цьому виявлено, що впродовж періоду загоєння рани пов'язка добре утримувалася на тілі тварин. Водночас пов'язка не схильна до фрагментації в рані при поглинанні нею ексудату. Вона зберігала цілісність, добре видалялася 3 рани під час перев'язок, мала високі межі міцності, що сприяло доброму захисту від механічних впливів на ранову поверхню (рис. 7). Армована пов'язка на основі пектину з вмістом хлоргексидину ізолювала ранову поверхню від механічного подразнення і бактеріального забруднення, забезпечувала водо-, повітро- і теплообмін між раною та зовнішнім середовищем, адсорбувала надлишок ексудату, підтримувала вологе середовище і не викликала гіперосмотичного ушкодження й висихання рани, що стимулювало процес регенерації. У тварин, в яких рани були інфікованими, встановлено інгібування росту мікроорганізмів.

Загоювання післяопераційної неінфікованої рани відбувається за первинним натягом впродовж 7 діб без утворення рубцевої тканини (рис. 8).

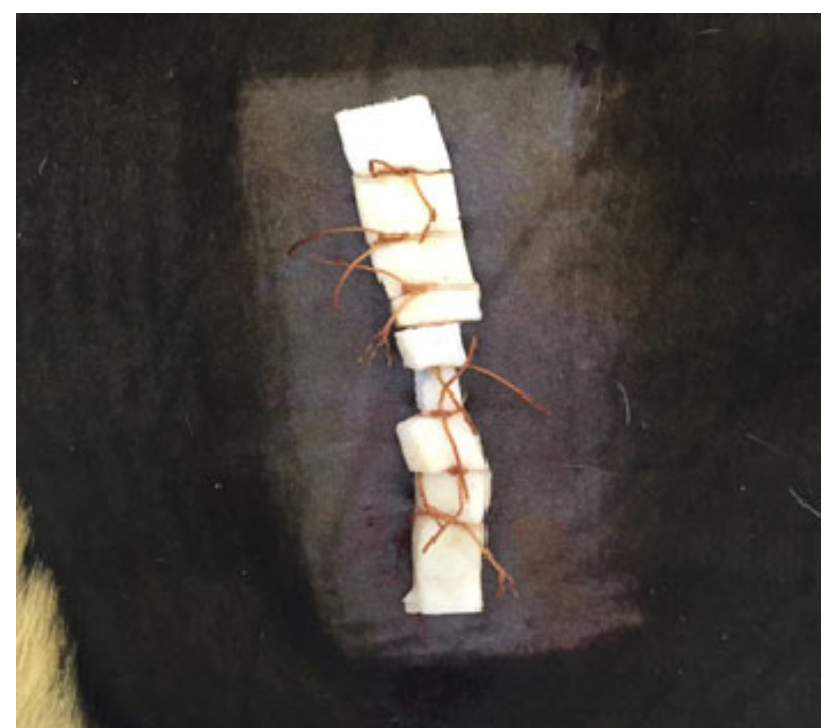

Рис 7. Армована пов'язка на основі пектину з поліпропіленовим елементом армування з вмістом хлоргексидину біглюконату на післяопераційній рані в ділянці черевної стінки великої рогатої худоби через

4 доби після проведення лапаротомії

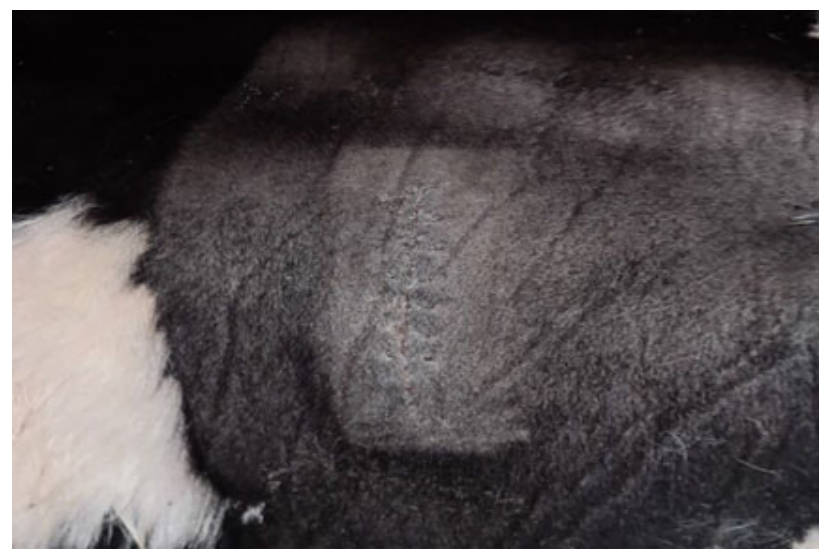

Рис. 8. Післяопераційна ділянка черевної стінки великої рогатої худоби після проведення лапаротомії через 7 діб

\section{Висновки}

1. Результатами клініко-експеримендальних досліджень доведено терапевтичну ефективність та практичну доцільність застосування армованої пов'язки на основі пектину з бавовняним (чи поліпропіленовим) елементом, насиченої антимікробним засобом - хлоргексидином біглюконатом для санації лапаротомних ран у великої рогатої худоби.

2. Гідрогелева пектинова пов'язка 3 вмістом $0,03 \div 1,5 \%$ хлоргексидину біглюконату пригнічує ріст як грампозитивних ( $S$. aureus), так і грамнегативних (P. aeruginosa) бактерій та профілактує розвиток інфекційно-запального процесу в післяопераційній рані.

3. Застосування армованої пов'язки на основі пектину з бавовняним (чи поліпропіленовим) елементом армування 3 вмістом хлоргексидину біглюконату скорочує витрати перев'язувального матеріалу і частоту перев'язок впродовж часу загоєння ран, створює 
достатній захист ранової поверхні від забруднення, механічного подразнення, бактеріальної контамінації та розвитку вторинної інфекції та забезпечує атравматичність і безболісність перев'язок.

4. Пов'язка сприяє доброму водо-, повітро- та теплообміну між раною і зовнішнім середовищем, адсорбує надлишок ексудату, підтримує вологе середовище і не викликає гіперосмотичного ушкодження й висихання рани, що відповідно поліпшує здатність травмованих тканин до регенерації.

Перспективи подальших досліджень. Буде продовжено дослідження армованої пов'язки на основі пектину 3 поліпропіленовим елементом із вмістом хлоргексидину біглюконату на ранових поверхнях шиї, холки, грудної й черевної стінок, попереку, крижів, стегна, плеча великої рогатої худоби. Подальші дослідження будуть стосуватися особливостей використання армованих пектинових пов'язок на поліпропіленовій основі із вмістом хлоргексидину біглюконату для інших видів тварин.

\section{Відомості про конфлікт інтересів}

Автори стверджують про відсутність конфлікту інтересів.

\section{References}

Abayev Y. K. (2006). Spravochnik khirurga. (Rany i ranevaya infektsiya). Feniks, Rostov-na-Donu (in Russian).

Andreyev, D. Y., Paramonov, B. A., \& Mukhtarova A. M. (2009). Sovremennyye ranevyye pokrytiya. Vestnik khirurgii, 1689(3), 98-101 (in Russian).

Anghel, I. (2012). Modified wound dressing with phytonanostructured coating to prevent staphylococcal and pseudomonal biofilm development. Nanoscale Research Letters, 7, 690. doi: 10.1186/1556-276X-7-690.

Blednov, A. V. (2006). Perspektivnyye napravleniya v razrabotke novykh perevyazochnykh sredstv. Novosti khirurgii, 1, 9-19 (in Russian).

Caló, E., \& Khutoryanskiy, V. (2015). Biomedical applications of hydrogels: A review of patents and commercial products. European Polymer Journal, 65, 252267. doi: 10.1016/j.eurpolymj.2014.11.024.

Cheng, C., Zhang, X., Meng, Y., Zhang, Z., Chen, J., \& Zhang, Q. (2017). Multiresponsive and biocompatible self-healing hydrogel: its facile synthesis in water, characterization and properties. Soft Matter, 13, 30033012. doi: 10.1039/C7SM00350A.

Dron', I. A., Nosova, N. H., Yakoviv, M. V., Bukartyk, M. M., Stasyuk, A. V., Varvarenko, S. M., Bordenyuk, O. Y., Maykovych, O. V., Fihurka, N. V., Samaryk, V. Y., \& Voronov, S. A. (2020). Sposib otrymannya antyseptychnoyi hidrohelevoyi pov'yazky. Patent. UA № 143783 U Byul. № 15 10.08.2020 (in Ukrainian).

Dron', I. A., Stasyuk, A. V., Bukartyk, M. M., Luhova, Y. R., \& Samaryk V. Y. (2020). Formuvannya hidroheliv na osnovi pektynu z riznym stupenem esteryfikatsiyi. Khimiya, tekhnolohiya rechovyn ta yikh zastosuvann- ya, 3(1), 239-244. doi:10.23939/ctas2020.01.239 (in Ukrainian)

Jones, V., Grey, J. E., \& Harding, K. G. (2006). ABC of wound healing. Wound dressings. BMJ, 332, 777780. doi: 10.1136/bmj.332.7544.777.

Li, W., Wang, B., Zhang, M., Wu, Z., \& Wei, J. (2020). All-natural injectable hydrogel with self-healing and antibacterial properties for wound dressing. Cellulose, 27, 2637-2650. doi: 10.1007/s10570-019-02942-8.

Mysak, A., Ostapiv ,D., Kuzmina, N., Kozak, M., Lukashchuk, B., Dron, I., Bukartyk, N., Bukartyk, M., \& Vlizlo, V. (2021). Application of dressings based on pectin hydrogel plates for healing aseptic wounds. Proceedings of the XX. Middle European Buiatric Congress. Ptuj/Slovenia, 49.

Mysak, A., Ostapiv, D., Dron', I., Bukartyk, N., Nosova, N., Varvarenko, S., Samaryk, V., \& Vlizlo, V. (2021). Stvorennya i aprobuvannya hidrohelevykh pektynovykh povyazok dlya likuvannya ran u tvaryn. IKH Mizhnarodna naukovo-praktychna konferentsiya "Veterynarni preparaty: rozrobka, kontrol' yakosti ta zastosuvannya", L'viv (in Ukrainian).

Nosova, N. H., Maykovych, O. V., Bordenyuk, O. Y., Yakoviv, M. V., \& Varvarenko S. M. (2020). Armuvannya al'hinat-zhelatynovoho hidrohelyu funktsionalizovanym polipropilenovym mikrovoloknom. Khimiya, tekhnolohiya rechovyn ta yikh zastosuvannya, $3(1), \quad 232-238$. doi: $10.23939 / \operatorname{ctas} 2020.01 .232$ (in Ukrainian).

Nosova, N., Bukartyk, M., Dron, I., Bukartyk, N., Ostapiv, D., Vlizlo, V., Mysak, A., \& Samaryk, V. (2021). Antiseptic hydrogel bandages for use in veterinary medicine. First Ukrainian-Polish Scientific Forum AGROBIOPERSPECTIVES., Lviv, Ukraine, 84 (in Ukrainian).

Ostapiv, D., Mysak, A., Kozak, M., Bukartyk, N., Nosova, N., Varvarenko, S., Samaryk, V., Len'o, YU., Fedorovych, V., Rusyn, V., Chernushkin, B., \& Vlizlo, V. (2021). Hidrohelevi pektynovi povyazky dlya likuvannya pislyaoperatsiynykh ran u velykoyi rohatoyi khudoby. II konferentsiya suchasni metody diahnostyky, likuvannya ta profilaktyka u veterynarniy medytsyni, prysvyachena 140-richchyu vidkryttya navchal'noho zakladu "Tsisars'ko-korolivs'ka veterynarna shkola ta shkola pidkovuvannya koney razom iz klinikoyu-statsionarom dlya tvaryn u L'vovi". L'viv (in Ukrainian).

Shablovskaya, T. A., \& Panchenkov, D. N. (2013). Sovremennyye podkhody $\mathrm{k}$ kompleksnomu lecheniyu gnoyno-nekroticheskikh zabolevaniy myagkikh tkaney. Vestnik eksperimental'noy i klinicheskoy khirurgii, 4(4), 498-507 (in Russian).

Yamane, T., Nakagami, G., \& Yoshino, S. (2013). Hydrocellular Foam Dressing Promotes Wound Healing along with Increases in Hyaluronan Synthase 3 and PPAR $\alpha$ Gene Expression in Epidermis. PLOS ONE, 8(8), e73988. doi: 10.1371/journal.pone.0073988. 